\title{
Avoiding Frustrations Of Unprepared Students With Online Quizzes
}

Anita Campbell, University of Cape Town, South Africa

Kanshukan Rajaratnam, University of Cape Town, South Africa

\begin{abstract}
The hierarchical nature of many degrees enables higher-level courses to build on knowledge that has been developed in earlier courses. However, when students enter with weak prior knowledge, lecturers have to spend time addressing this before starting with the new material. This adds time pressure and frustration to lecturers as well as students who have strong prior knowledge. In this paper, we discuss a strategy that we implemented in order to encourage students to revise or learn prerequisite material at the beginning of a master's level module. Students were asked to take an online quiz on the prerequisite topics. Immediate feedback directed the students to resources which could enhance their knowledge and understanding of the material prior to course commencement. We discuss the multiple benefits this had, for both students and the lecturer, drawing on students' written responses to reflective questions about the experience and reflections from the lecturer on the use of online quizzes.
\end{abstract}

Keywords: Online Quiz; Prerequisite Knowledge; Students

\section{INTRODUCTION}

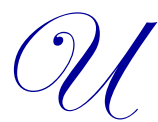

niversity degree curriculums are designed in a hierarchical manner. Students generally follow a sequence of courses in order to fulfil the requirement for a major. For example, students at the University of Cape Town undertake Finance I, Finance II and Finance III, in that order, to major in finance. Most often, such sequences of courses are structured such that the knowledge learnt in earlier courses is required for the latter courses. Alternatively, courses could be structured in a manner such that the latter years' topics require some cognitive maturity that can be gained by undertaking and passing the earlier courses.

Despite quality control measures, it appears that many students pass earlier courses with shallow or partial understanding, possibly as a result of poor learning choices such as 'cramming' and aiming to pass the course with minimum effort. Given that students had passed the earlier courses, they are allowed entry into the latter courses but may bring inadequate knowledge from the previous courses. This poses a dilemma for the lecturer. If a lecturer ignores the issue in the hope that weaker students will take the responsibility in learning the prerequisite topics, time can be spent on the new material, but students with low prerequisite knowledge might struggle through the material and hence never have an opportunity to truly understand the new material. Many students in such a predicament then aim to merely pass the course rather than gain a deep understand of the topics.

On the other hand, a lecturer might re-teach the prerequisite topics. When the syllabus is predetermined and does not include class time for revision, this strategy reduces the class time available for new and more challenging topics. The added time pressure reduces opportunities for lecturers to enhance students' understanding of the new material. In addition, students who enter with adequate knowledge of the prerequisite topics may find spending class time on older topics to be a frustrating, time-wasting experience.

\section{Project Rationale}

The authors were interested to implement a strategy to ensure students learn and understand the prerequisite topics prior to the start of a new topic. However, it was important to place the onus on the student to learn the material rather than revising the prerequisite topics during class time. 
To ensure buy-in from students, the process was strategically designed with certain characteristics. Firstly, the revision tasks should be brief to maximise the chance that students will perform the tasks. The authors were acutely aware of the time pressures faced by students. Secondly, the resources used in aiding students to learn prerequisite material must be easily accessible. From the authors' experience, students don't want to spend much time in finding resources. Thirdly, immediate feedback on the student's knowledge of the prerequisite material was important. Due to the quick succession of topics in the course, students are impatient for feedback. The authors' experiences in other courses have shown that when students did not receive immediate feedback and had moved on to other topics in the course, they benefitted less from the feedback. Fourthly, given that multiple topics are taught in the course with each topic requiring different prerequisite knowledge, it was important to design the process in a manner that students revise their prerequisite knowledge close to when it would be needed.

There were other considerations in designing the process. All students have access to the internet and to computers on campus. A large majority of postgraduate students have access to their own laptops, smartphones and other devices that may be used to access the internet. An online quiz seemed an appropriate medium in designing the system as it is easily accessible by our students and little interaction and effort is needed by the course convener once the system is set up.

In the sections that follow, we review some theories of learning and principles for the effective use of technology in education. We compare online quiz platforms and describe the benefits and limitations of the platform used in this study - ClassMarker. Next we describe the intervention strategy that was implemented in a master's level course, where the onus was placed on the students to recap and learn the prerequisite topics they were weak in, as identified by an online quiz. Finally, we discuss the lecturer and student feedback that revealed surprising benefits for both the lecturer and students beyond relieving time pressure and frustration.

\section{THEORIES OF LEARNING}

The complexity of the task of understanding human learning has given rise to many theories. The value of the existence of multiple educational theories has been discussed by Lerman (2006). We have grounded our understanding of the benefits of online quizzes in the theories of constructivism, deep learning, cognitive complexity and connectivism.

\section{Constructivism}

The dominant learning theory of constructivism (Fosnot, 1996; Duffy \& Cunningham, 1996) views learning as a process of active construction of knowledge by learners rather than the transmission and absorption of knowledge. This is achieved by establishing links between new knowledge still to be learned and existing knowledge or experiences. Optimal learning occurs when the gap between what is to be learned and what is already known is sufficiently large to challenge the learner but small enough that links to prior knowledge can readily be made. In a constructivist framework, it is clear that the learning of higher-level knowledge will benefit from welldeveloped prior knowledge. The use of quizzes to develop prior knowledge is therefore advantageous for learning.

The gap between known and unknown knowledge, described by Vygotsky (1978) as the 'zone of proximal development', is influenced by life experiences and personal development and is therefore different for each learner. Teaching activities can support learners by providing 'scaffolding' to reduce the size of a 'too large' gap by clarifying the links between known and new concepts. A revision quiz, as used in this study, can be seen as a form of scaffolding, the usefulness of which will depend on each learner's needs.

Active learning is a teaching approach based in constructivism and is widely accepted as good teaching practice (Prince, 2004; Johnson, Johnson \& Smith, 1991; Michael, 2006; Zepke \& Leach, 2010). Quizzes have been used in classes to increase students' active engagement, using 'clickers,' mobile phones, or computers as response systems (Martyn, 2007; Cheung \& Hew, 2009; Perišić, 2012). Deeter (2008) noted that online quizzes promoted self-dialogue in students as they questioned what they were learning. An online quiz can be made more active by providing an online space for students and lecturers to share resources they have found useful, discussing quiz answers in class and in online chat rooms, or having students set questions and provide feedback. This would also tie in with social learning theories that acknowledge the importance of engaging with others in learning. 


\section{Cognitive Complexity And Deep Learning}

Bloom's taxonomy of learning (Anderson et al., 2000) provides another continuum for describing learning, using six hierarchical levels of cognitive complexity. The lowest three levels involve recall, understanding and applying previously learnt concepts. While educators are encouraged to move students up through the higher levels of analysing, evaluating and creating, the lower-level stages may be more appropriate for quickly revising concepts to enable the higher-level learning.

Ke and Xie (2009) describe surface and deep learning as opposite ends in a continuum, with surface learning corresponding to simple memorization and deep learning corresponding to active integration of new ideas using social negotiation. In an in-depth discussion of the concepts of surface and deep learning, Beattie, Collins and McInnes (1997) point out that although a deep approach is generally desirable, there may be times when a surface (or rote learning) approach is more appropriate. Revision quizzes that involve recall of terms or definitions can be seen as developing surface knowledge or the lower-levels of learning on Bloom's taxonomy.

Deep knowledge of a complex topic, such as in a senior-level university course, depends on a firm understanding of related concepts, many of which would have been taught in other courses. A limitation of this is that few students pass a course with a complete understanding of all the topics. Instead, it is assumed that students with a minimum threshold of understanding, usually equated to a course mark of $50 \%$, will be able to develop sufficiently to understand the new material. It is typically assumed by a lecturer that the student should take responsibility for ensuring that they understand the prerequisite material before or while learning new content that draws on it. This is often not due to ignorance or a lack of care on the part of the lecturer, but rather because the demands of teaching and assessing a higher-level course don't allow for a great focus on work that should have been mastered in a previous course.

\section{Connectivism}

In the learning theory of connectivism (Siemens, 2005), learning is seen as creating and navigating networks of knowledge. A lecturer can promote more effective learning by creating diverse opportunities for students to connect with ideas and people. Online revision quizzes can support this, for example, by linking a quiz question to resources (such as textbooks, websites and online chat rooms) where the topic is explained further. Revising previously learnt concepts shortly before they will be built on should make it easier for connections to be made between old and new concepts. A revision quiz can help learners navigate through a large collection of information by allowing students to test their understanding and quickly access relevant resources if they need to.

\section{PRINCIPLES FOR THE EFFECTIVE USE OF TECHNOLOGY IN EDUCATION}

The increasing availability of a variety of educational technology tools (Weller, 2011) requires decisions about incorporating technology into teaching to be based on sound principles (Kirkwood \& Price, 2011). A guiding principle for selecting technology to enhance teaching is: "How well do the affordances of this tool (Bower, 2008) match the learning needs?" The features we felt would be valuable in an online quiz platform were:

- $\quad$ Be user-friendly for setting up and taking the questions

- $\quad$ Support multiple choice as well as free-response questions

- $\quad$ Support the display of mathematics in questions and feedback

- $\quad$ Give individual feedback for all multiple choice options

- Include links to static resources (e.g. websites, textbooks) and dynamic resources (e.g. multilingual glossary, wiki, email link to lecturer) in feedback

- $\quad$ Provide statistics on quiz takers' use and performance

- $\quad$ Allow students to take quizzes in their own time on their own or university devices

- $\quad$ Support a range of class sizes

- Be inexpensive 
The selection of an educational technology tool also needs to take into account the needs, practices and resources of the students. The use of just-in-time online quizzes seemed to match students' time-pressured lifestyles by providing immediate feedback, easy-to-access resources, and sufficient time to access resources so that they could be optimally prepared for drawing on prior knowledge when it was needed in class. Quizzes could be taken before the start of a course or before weekends to allow for revision time. All students have free internet access on campus and most have their own laptops or smartphones, making it easier to fit in time to take the quiz outside of class. Furthermore, taking quizzes privately would save embarrassment for students compared to exposing their weaknesses in class in front of their peers. A strong advantage of an online quiz for lecturers was that once a quiz was set up, it required minimal effort for data extraction and future use.

Online quizzes also allow for self-directed learning to be balanced with guidance. The option for lecturers to add written comments, when manually marking essay-type responses and the option for students to email the lecturer easily while taking the quiz, are features that can increase the social contact and guidance from lecturers that students have been shown to value (Siemens \& Tittenberger, 2009).

Apart from considering the affordances of online quizzes and how they would be a suitable match for students, we also considered how they related to Chickering \& Ehrmann's (1996) seven principles for good online learning. Table 1 lists the seven principles and how we see online quizzes meeting these principles.

Table 1: Online Quizzes In Relation To Chickering \& Ehrmann's Seven Principles For Good Online Learning

\begin{tabular}{|l|l|l|}
\hline Principle For Good Online Learning & \multicolumn{1}{c|}{ How Online Quizzes Address This Principle } \\
\hline 1 & $\begin{array}{l}\text { Good practice encourages contacts } \\
\text { between students and faculty. }\end{array}$ & $\begin{array}{l}\text { Lecturers use quiz results to better understand their students. Lecturers' email } \\
\text { links in the quiz and the option for individual written feedback from lecturers } \\
\text { can encourage student-lecturer contact. }\end{array}$ \\
\hline 2 & $\begin{array}{l}\text { Good practice develops reciprocity and } \\
\text { cooperation among students. }\end{array}$ & $\begin{array}{l}\text { Students can suggest resources they found helpful for the purpose of helping } \\
\text { other students. }\end{array}$ \\
\hline 3 & Good practice uses active learning. & Quizzes are active. \\
\hline 4 & Good practice gives prompt feedback. & Feedback is immediate when answers are submitted. \\
\hline 5 & Good practice emphasizes time on task. & $\begin{array}{l}\text { Quiz performance can guide students to spend focussed time on necessary } \\
\text { revision so that new tasks can be completed in good time or time in lectures is } \\
\text { not wasted due to not being able to follow the lecturer. }\end{array}$ \\
\hline 6 & $\begin{array}{l}\text { Good practice communicates high } \\
\text { expectations. }\end{array}$ & $\begin{array}{l}\text { Quizzes test work that should be mastered. Students can take the quizzes } \\
\text { before starting the course. }\end{array}$ \\
\hline 7 & $\begin{array}{l}\text { Good practice respects diverse talents } \\
\text { and ways of learning. }\end{array}$ & $\begin{array}{l}\text { Feedback on questions can link to a variety of resources e.g. text, videos, } \\
\text { podcasts, tutorials, chat rooms. Students can add to these and rate them. }\end{array}$ \\
\hline
\end{tabular}

(Chickering \& Ehrmann, 1996)

\section{CHOICE OF ONLINE PLATFORM}

In Bertea's (2012) useful comparison of ten online quiz platforms, only three platforms could provide statistics on the quiz takers engagement with a quiz. The most economical platform meeting our needs was ClassMarker, which has been used successfully in other studies involving online quizzes, e.g. Baker and Rees (2008). 
We compared features in ClassMarker with two free quiz platforms available through our university WeBWorK, a free database for Mathematics educators supported by the Mathematics Association of America and the US National Science Foundation, and Vula, our Sakai-based Learning Management System. The results are detailed in Table 2.

Table 2: A Comparison Of Online Quiz Platforms

\begin{tabular}{|l|c|c|c|}
\hline & ClassMarker & WeBWorK & Vula \\
\hline $\begin{array}{l}\text { Database of } \\
\text { existing } \\
\text { questions }\end{array}$ & $\begin{array}{c}\text { Yes, limited access to a } \\
\text { growing database }\end{array}$ & $\begin{array}{c}\text { Yes, large textbook-specific database } \\
\text { (excluding the prescribed textbook for } \\
\text { this course) }\end{array}$ & $\begin{array}{c}\text { No } \\
\text { Cost }\end{array}$ \\
\hline Advertising & Free and pay options & Free & $\begin{array}{c}\text { Adverts for university } \\
\text { activities at login }\end{array}$ \\
\hline $\begin{array}{l}\text { Tracking } \\
\text { students' } \\
\text { progress }\end{array}$ & $\begin{array}{c}\text { Easy to display and export } \\
\text { marks and quiz taker } \\
\text { statistics. }\end{array}$ & $\begin{array}{c}\text { Easy to display and export marks and } \\
\text { quiz taker statistics. }\end{array}$ & $\begin{array}{c}\text { Easy to display and export } \\
\text { marks and quiz taker } \\
\text { statistics. }\end{array}$ \\
\hline $\begin{array}{l}\text { Aesthetics } \\
\text { Ease of use }\end{array}$ & $\begin{array}{c}\text { Visually appealing. } \\
\text { Navigation easy for users and } \\
\text { quiz setters }\end{array}$ & $\begin{array}{c}\text { Navigation through many menus, feels } \\
\text { old. }\end{array}$ & $\begin{array}{c}\text { Unattractive colours and } \\
\text { small font. }\end{array}$ \\
\hline Other & $\begin{array}{c}\text { Overseas server, email and } \\
\text { online help available }\end{array}$ & $\begin{array}{c}\text { Local server, local technical help } \\
\text { available }\end{array}$ & $\begin{array}{c}\text { Local server, local technical } \\
\text { help available }\end{array}$ \\
\hline
\end{tabular}

The ease of use, clarity of display, and the ability to provide individual feedback for responses led us to choose ClassMarker for this project. It allowed for quizzes to be saved so that students could work on them in small chunks of time. The main limitation of the package was that it had to be accessed through the internet and relied on an uninterrupted internet connection. This was the case for all web-based platforms, but we felt that the difficulties associated with limiting users to computers that have quiz software installed outweighed the risk of broken internet connectivity.

\section{INTERVENTION STRATEGY}

\section{Background}

In order to provide context, we describe the course where the strategy was implemented. The master's programme in investment management is a part coursework and part research master's programme offered at the University of Cape Town (UCT). Students are required to complete two semester-long courses and undertake a research project. The second course consists of various investment topics. The particular topic taught by one of the authors was fixed income, taught over two weeks. Since this was at the master's level, students were expected to know and understand fixed income (or bonds) topics taught in their undergraduate studies. However, students may be accepted into the master's programme after graduating from finance or finance-related undergraduate studies. Furthermore, students from other universities with similar majors may be granted entrance into the master's programme. All students were expected to have the same knowledge as taught in UCT's undergraduate finance courses, Finance I and Finance II although they may not have taken these specific courses.

\section{Implementation}

Students were asked to take an online quiz that covered the fixed income topics taught at undergraduate level. Our strategy was to ask the students to take a multiple choice quiz in their own time using the ClassMarker platform. On completion of each question, immediate feedback was given. For questions where the correct answer was chosen, the complete solution was given to allow students to check their mathematical methods. When the wrong answer was chosen, the feedback included both the correct solution as well as directions to resources in order to relearn the material. The students were directed to textbooks that are currently prescribed in the undergraduate Finance II course. 
At the end of the quiz, students were asked to respond to free-response questions on the experience of taking the quiz. Semi-structured interviews with students after the course also provided feedback on the design of the quiz. The lecturer's written and spoken reflections on the experience were a third data set.

Figure 1 shows a question from a ClassMarker quiz that has been submitted for marking. The incorrect answer is marked with a cross and the correct answer is marked with an arrow. The heading 'Feedback' denotes feedback for an incorrect answer to this question. Students are referred to pages in the prescribed textbook. The feedback can be customised so that students can reattempt the quiz before seeing the correct answers.

\section{Question 10 of 13}

Is a Mortgage-backed Security (MBS) like a callable bond? If yes, why?

Correct answer: C)
Selected answer: A)

$\times$ A) An MBS has no callable option and hence it is not similar to a callable bond.

B) The prepayment option of an MBS can only be exercised by consumers and not the institution selling the bond. Hence an MBS is dissimilar to a callable bond.

$\Rightarrow$ C) The prepayment option of an MBS that can be exercised by consumers is a callable option where the principal is paid up earlier. Hence an MBS is similar to a callable bond.

D) The MBS holder holding a credit default swap on the bond will receive the principal up front when a consumer exercises an option to default. Hence an MBS is similar to a callable bond.

Points: 0 out of 1

Edit points

\section{Feedback:}

Read page 551 and 554 of section 16.2. An MBS consists of a number of mortgages. When an institution buys an MBS, they are effectively loaning money to these consumers (even though the actual loaning took place prior to the MBS transaction). In such a setup, the consumer is similar to a bond seller and any individual seller (or consumer) may pre-pay their principal at any time, i.e., exercising their callable option.

Figure 1: Feedback Displayed For A Question With An Incorrect Answer On Classmarker

\section{FINDINGS}

\section{Lecturer's Response}

The lecturer felt class time was used more appropriately to teach the harder master's level topics. Unsurprisingly, this freed up a lot of time not only to teach the subject but also to implement those strategies that encourage deep learning of the material. For example, the effective use of class time meant the lecturer could spend the first hour teaching new topics and the second hour of each class implementing the topics in practical terms. Students' responses were extremely positive to having the second hour for implementing the theory into practice. The freed-up time also meant that student questions were more effectively answered, which often led to more interesting and sophisticated questions from the students. Since students seemed to understand the material better, 
the lecturer felt greater satisfaction in teaching this topic. In addition, students with greater understanding of the prerequisite material did not feel the frustration of sitting through topics that they already knew and understood well. The following email quote from the lecturer shows that an online quiz may be an especially useful tool for new lecturers or those who are teaching a topic that is new to them:

I have taught bonds before at $2^{\text {nd }}$-year level for about a week. Other than that, I don't have much knowledge of bonds, so teaching at the master's level is kind of nerve wrecking. However, having the students do the quiz ... made it much easier because suddenly we are on the same page and my expectation of prerequisite knowledge was set up. I really don't think it would have been as easy to lecture as it was yesterday if I didn't have them do something like this quiz prior to class. Lecturer, 26 September 2012.

\section{Students' Responses}

As expected, the usefulness of the quiz depended on students' understanding and recollection prior knowledge. Some found that they were "a bit rusty on the concepts" and that all the questions "took a bit of time to figure out." A student who was tutoring on the Finance II course, where the prerequisite work was taught, commented that "nothing was learned or revised from the quiz." Nevertheless, and surprisingly, this student still found the quiz a "useful refresher."

Regarding the ease of use of the quiz, most students experienced no technical difficulties. The feature of being able to "save and come back and pick up where you left off" was appreciated. However, one student reported being "logged out mid-test" due to a break in the internet connection.

Interviews with students gave useful feedback regarding the timing and extent of the quizzes. All the interviewed students felt that the use of revision quizzes should be extended to all the topics in the course. Given the choice between taking multiple quizzes at the beginning of the course or taking the quiz as each topic starts, students unanimously chose the former as it allowed for more revision time.

\section{DISCUSSION AND CONCLUSION}

Students found the experience of taking an online quiz useful, even if the work was familiar. Seen through a constructivist lens, the development of prerequisite knowledge would make it easier for students to bridge the gap between the known and the unknown while they make meaning out of the new knowledge. Although the use of revision quizzes draws on the lower-order thinking processes in Bloom's taxonomy, such as remembering, understanding and applying (Dowling, 2011), the purpose of this intervention was to enable students to reach deeper learning in new topics. In this study, the lecturer found that the students' greater understanding of the prerequisite knowledge led to deeper discussions on the topic during class and that time saved on not revising prerequisite topics in class gave more class time for practical implementation of theory. All this should have promoted deeper understanding of the topic.

This study used an online quiz with a small class, but the potential benefits to the lecturer and students might be even greater in a large class where personal access to the lecturer is limited. Using an online quiz, every student in the class can receive lecturer-designed feedback specific to their difficulties, with time-saving, expert advice on resources where specific help can be found. In return, lecturers get an accurate overview of student engagement and areas of difficulty, which can inform lecture preparation.

The convenience from students being able to take the quiz on their personal internet-connecting devices without having to download software was seen to outweigh the risks associated with using an internet-based quiz. If this strategy was to be used with a different student population, such as a large first-year class, consideration should be given to ensuring that all students have adequate opportunities to take revision quizzes. As this study involved master's level students, it would be interesting to see if the effects would be different for a different audience, such as first-year students. 
The most compelling benefits of revising prerequisite material through online quizzes are that class time does not need to be spent revising prerequisite concepts and lecturers can get up-to-date and detailed information on their students' strengths and weaknesses in terms of prerequisite information. The feedback from such quizzes can also be helpful for lecturers in prerequisite courses and assist in creating stronger links between courses. It is also possible that there might be a motivational effect from taking a quiz to prepare for lectures. Future studies could investigate these relationships further.

\section{AUTHOR INFORMATION}

Anita Campbell is an Academic Development Lecturer in the Academic Support Programme for Engineering in Cape Town (ASPECT) and a member of the Centre for Research in Engineering Education (CREE) at the University of Cape Town. Her research interests are mathematics education, student success and educational technology. She has fourteen years of experience teaching first-year mathematics to commerce, science and engineering students and is a council member for the Western Cape branch of the Association for Mathematics Education of South Africa (AMESA). E-mail: anita.campbell@uct.ac.za (Corresponding author).

Kanshukan Rajaratnam is a Senior Lecturer of Finance and is an associate of the African Collaboration for Quantitative Finance and Risk Research (ACQuFRR) at the University of Cape Town, South Africa. His research interests lie in decision-making in consumer credit loans, Basel Accord and teaching practices. He is a member of the Operations Research Society of South Africa (ORSSA). E-mail: kanshukan.rajaratnam@uct.ac.za

\section{REFERENCES}

1. Anderson, L. W., Krathwohl, D. R., Airasian, P. W., Cruikshank, K. A., Mayer, R. E., Pintrich, P. R., Raths, J. \& Wittrock, M. C. (Eds.) (2000). A Taxonomy for Learning, Teaching, and Assessing: A Revision of Bloom's Taxonomy of Educational Objectives. Boston: Allyn \& Bacon.

2. Baker, D. A. \& Rees, M. J. (2008). WILE: A very low cost web-based integrated learning environment, 14th Australasian World Wide Web conference: AusWeb 08. Ballina, Australia, April 2008. Retrieved from http://epublications.bond.edu.au/infotech pubs/116, accessed on 21 February 2013.

3. Beattie, V., Collins, B. \& McInnes, B. (1997). Deep and surface learning: a simple or simplistic dichotomy? Accounting Education: An International Journal, 6(1), 1-12.

4. Bertea, A. F. (2012). Better student learning achievement evaluation by using dedicated freeware eassessment tools. In Proceedings of the 8th International Scientific Conference "eLearning and software for Education,” Bucharest, 26-27 April 2012, (pp. 422-427). Retrieved from www.ceeol.com, accessed 21 February 2013.

5. Bower, M. (2008). Affordance analysis - matching learning tasks with learning technologies, Educational Media International, 45(1), 3-15.

6. Cheung, W. S. \& Hew, K. F. (2009). A review of research methodologies used in studies on mobile handheld devices in K-12 and higher education settings. Australasian Journal of Educational Technology, 25(2), 153-183. Retrieved from http://www.ascilite.org.au/ajet/ajet25/cheung.html, accessed 21 February 2013.

7. Chickering, A. W. \& Ehrmann, S. C. (1996). Implementing the Seven Principles: Technology as Lever, AAHE Bulletin, October, 3-6. Retrieved from http://www.tltgroup.org/programs/seven.html, accessed 21 February 2013.

8. Deeter, C. L. (2008). The effect of online quizzes on student achievement in high school chemistry. Unpublished doctoral dissertation. Lincoln, Nebraska: University of Nebraska.

9. Dowling, S. (2011). Web-based Learning: Moving from learning islands to learning environments. TESL$E J, 15(2), 1-27$. Retrieved from http://www.tesl-ej.org/wordpress/issues/volume15/ej58/ej58int/, accessed 21 February 2013.

10. Duffy, T. M. \& Cunningham, D. J. (1996). Constructivism: Implications for the design and delivery of instruction. In D. Jonassen (Ed.), Handbook of research for educational communications and technology. New York: Simon \& Schuster Macmillan.

11. Fosnot, C. W. (Editor). (1996). Constructivism, theory, perspectives, and practice. New York: Teachers College Press. 
12. Johnson, D. W., Johnson, R. T. \& Smith, K. A. (1991). Active Learning: Cooperation in the College Classroom. Edina, USA: Interaction Book Company.

13. Ke, F. \& Xie, K. (2009). Toward deep learning for adult students in online courses. The Internet and Higher Education, 12(3-4), 136-145.

14. Kirkwood, A. \& Price, L. (2011). Enhancing learning and teaching through technology: A guide to evidence-based practice for academic developers. York, UK: Higher Education Academy.

15. Lerman, S. (2006). Theories of mathematics education: Is plurality a problem?.Zentralblatt für Didaktik der Mathematik, 38(1), 8-13.

16. Martyn, M. (2007). Clickers in the classroom: An active learning approach. EDUCAUSE Quarterly, 2, 7174. Retrieved from http://www.educause.edu/ero/article/clickers-classroom-active-learning-approach, accessed 21 February 2013.

17. Michael J. 2006. Where's the evidence that active learning works? Advances in Physiology Education, 30(4), 159-167.

18. Perišić, V. (2012). Zappers in teaching mathematics. In Proceedings of the1st Annual Conference on the Aiming for Excellence in STEM Learning and Teaching, 12 - 13 April 2012, Imperial College, London \& The Royal Geographical Society. Retrieved from http://www.heacademy.ac.uk/assets/documents/stemconference/MSOR/Vesna_Perisic.pdf, accessed 17 May 2013. London: Higher Education Academy.

19. Prince, M. (2004). Does active learning work? A review of the research. Journal of Engineering Education, 93(3), 223-231.

20. Siemens, G. (2005). Connectivism: A learning theory for the digital age. International Journal of Instructional Technology \& Distance Learning, 2(1), 3-10. Retrieved from http://www.itdl.org/Journal/Jan_05/article01.htm, accessed 21 February 2013.

21. Siemens, G \& Tittenberger, P (2009). Handbook of Emerging Technologies for Learning. Retrieved from http://techcommittee.wikis.msad52.org/file/view/HETL.pdf, accessed 21 February 2013.

22. Vygotsky, L. S. (1978). In Cole, M., John-Steiner, V., Scribner S. and Souberman, E. (Eds.), Mind in society: The development of higher psychological processes. Cambridge, Massachusetts: Harvard University Press.

23. Weller, M. (2011). The Digital Scholar: How Technology is Transforming Scholarly Practice. London: Bloomsbury Academic. Retrieved from http://www.bloomsburyacademic.com/view/DigitalScholar_9781849666275/chapter-ba-9781849666275chapter-013.xml, accessed 5 June 2012.

24. Zepke, N. \& Leach, L. (2010). Improving student engagement: Ten proposals for action. Active Learning in Higher Education, 11(3), 167-177. 
NOTES 